$5-2004$

Delayed childbearing and maternal mortality

Marleen Temmerman

Hans Verstraelen

Guy Martens

A Bekaert

Follow this and additional works at: https://ecommons.aku.edu/eastafrica_fhs_mc_obstet_gynaecol 


\title{
Delayed childbearing and maternal mortality
}

\author{
M. Temmerman ${ }^{\mathrm{a}, \mathrm{b},{ }^{*}}$, H. Verstraelen ${ }^{\mathrm{a}}$, G. Martens ${ }^{\mathrm{a}, \mathrm{b}}$, A. Bekaert ${ }^{\mathrm{b}}$ \\ ${ }^{a}$ Department of $O B / G Y N$, Faculty of Medicine and Health Sciences, Ghent University, \\ De Pintelaan 185, 9000 Ghent, Belgium. \\ ${ }^{\mathrm{b}}$ Study Centre for Perinatal Epidemiology, Hallepoortlaan 27, 1060 Brussels, Belgium
}

Received 31 January 2003; received in revised form 23 July 2003; accepted 5 September 2003

\begin{abstract}
Objectives: To assess the maternal age trend in pregnant women in Flanders, Belgium, and examine the impact of maternal age on maternal mortality. Study design: Retrospective analysis of a population based regional perinatal database during one decade. Results: Between 1991 and 2000 a significant increase in maternal age was found, in primiparous as well as in multiparous women. The maternal mortality ratio was 5.8, and strongly related to maternal age, with a relative risk of 7.0 (95\% CI: 3.0-16.2) from the age of 35 on, and of 30.0 (95\% CI: 11.4-80.6) in women aged 40 years or beyond. Conclusions: These data call for further research and action to facilitate career and reproduction, and for special care for older pregnant women.
\end{abstract}

(C) 2003 Elsevier Ireland Ltd. All rights reserved.

Keywords: Maternal age; Maternal mortality

\section{Introduction}

Nowadays, many women choose to delay childbearing until their 30's and even their 40's because of multiple reasons. At the same time, it has been extensively documented that both obstetric complications as well as obstetric interventions occur at a significantly higher rate with advanced ( $\geq 35$ years) and higher ( $\geq 40$ years) maternal age, such as increasing rates of gestational diabetes, hypertension, placenta praevia, preterm birth, intra-uterine growth retardation and operative delivery with maternal age [1-4]. Consequently, higher maternal age has been a longstanding risk factor for maternal mortality and therefore has become a growing concern in this era of delayed childbirth. The use of maternal mortality as an indicator of maternal health has been challenged [5], for its occurrence is fairly low in most developed countries. Others have recently re-emphasized maternal deaths being considered a sentinel event [6], that is, an unnecessary disease, disability or ultimely event which justifies carefully controlled scientific search for remediable underlying causes [7]. From this perspective we decided to review the maternal age and maternal mortality data for the past decade.

\footnotetext{
* Corresponding author. Tel.: +32-9-2403796; fax: +32-9-2403831. E-mail address: marleen.temmerman@rug.ac.be (M. Temmerman).
}

\section{Methods}

Pregnancy-related deaths in Flanders, Belgium from 1991 to 2000 were identified through linkage of official death certificates and medical birth certificates abstracted from the Birth Registry of the Study Centre for Perinatal Epidemiology. The computerized perinatal database collects a limited number of variables of all births in Flanders, Belgium [8]. Data on maternal age, other demographic characteristics, medical and obstetric history, pregnancy outcome and maternal mortality in particular were collected. Subsequently, as part of a confidential inquire, a standardized questionnaire was administered to the certifying obstetricians and additional information on these maternal deaths was obtained for 34 out of the 37 maternal casualties.

The definitions used for the present study were adopted from the WHO ICD-10 manual [9].

For the present purpose, where referred to the overall number of maternal casualties the ICD-10 definition of pregnancy-related death is handled, unless otherwise specified.

Under ICD-10, maternal death is defined as "the death of a woman while pregnant or within 42 days of the termination of the pregnancy, irrespective of the duration and the site of the pregnancy, from any cause related to or aggravated by the pregnancy or its management but not from accidental or 
incidental causes".Maternal deaths are considered to be either:

(a) direct obstetric deaths, that is, deaths resulting from obstetric complications of the pregnant state (pregnancy, labour and puerperium); from interventions, omissions or incorrect treatment; or from a chain of events resulting from any of the above, or;

(b) indirect obstetric deaths, that is, deaths resulting from previous existing disease or disease that developed during pregnancy, which was not due to direct obstetric causes but which was aggravated by the physiologic effects of pregnancy. Hence, under ICD-10, deaths from any cause other than perinatal conditions, injury and poisoning (and direct obstetric causes) are classifiable as indirect obstetric deaths if the underlying condition was believed to have been aggravated by pregnancy.

According to ICD-10, late maternal death includes deaths from direct or indirect causes that occur more than 42 days but less than a year following the termination of pregnancy.

Finally, the ICD-10 category pregnancy-related death, includes all deaths that occur during pregnancy or within 42 days of the termination of pregnancy regardless of the cause or whether the certifying physician believed the underlying cause was aggravated by the pregnancy. The category therefore also includes all intentional and unintentional deaths from injury and poisoning.

The incidence of pregnancy-related deaths is defined as the maternal mortality ratio, that is the number of maternal deaths per 100,000 live births [9]. The reported maternal mortality ratio therefore includes all direct and indirect obstetric deaths, as well as coincidental deaths that occurred during pregnancy or within 42 days of the termination of pregnancy.

Statistical analysis was carried out using SPSS $(C)$ version 10.0 (SPSS Inc. Chicago, IL, USA) statistical package. Yates corrected $\chi^{2}$ testing was used to compare proportions, relative risks and their $95 \%$ confidence intervals were used to measure strength of associations.

\section{Results}

From 1991 to 2000, the Study Centre for Perinatal Epidemiology collected data on 630,544 deliveries, resulting in 642,609 births, including 639,365 live births. These data represent over 99\% of all deliveries in Flanders, Belgium. During this 10-year study period, mean maternal age increased from 26.3 years to 27.5 in nulliparous women and from 29.4 to 30.7 for multiparae.

During this decade, 37 women were reported to have died during pregnancy or within 42 days following delivery which equals 5.8 pregnancy-related deaths per 100,000 live births under the ICD-10 classification (Table 1). There were 24 direct maternal deaths (3.8 deaths per 100,000 mater-
Table 1

Underlying and eventual cause of death for maternal deaths in Flanders, 1991-2000

\begin{tabular}{|c|c|c|c|}
\hline Underlying cause of death & $\begin{array}{l}n \\
(N=37)\end{array}$ & $\begin{array}{l}\text { Eventual cause } \\
\text { of death }\end{array}$ & \\
\hline $\begin{array}{l}\text { Thromboembolism } \\
\text { Pulmonary embolism } \\
\text { Amniotic fluid embolism }\end{array}$ & $\begin{array}{r}12 \\
7 \\
5\end{array}$ & & \\
\hline $\begin{array}{l}\text { Hypertensive disorders } \\
\text { HELLP }\end{array}$ & $\begin{array}{l}6 \\
3\end{array}$ & $\begin{array}{l}\text { ARDS } \\
\text { Intracerebral } \\
\text { haemorrhage }^{\text {a }}\end{array}$ & $\begin{array}{l}2 \\
1\end{array}$ \\
\hline Hepatic necrosis & 2 & $\begin{array}{l}\text { Intracerebral } \\
\text { haemorrhage }^{\mathrm{a}}\end{array}$ & 1 \\
\hline $\begin{array}{l}\text { Haemorrhage } \\
\text { Uterine rupture } \\
\text { Atony } \\
\text { Placental abruption (+DIC) } \\
\text { DIC of unknown origin }\end{array}$ & $\begin{array}{l}6 \\
3 \\
1 \\
1 \\
1\end{array}$ & & \\
\hline $\begin{array}{l}\text { Cardiac disease } \\
\text { Acute heart failure } \\
\text { Post-partum cardiomyopathy }\end{array}$ & $\begin{array}{l}4 \\
1 \\
3\end{array}$ & $\begin{array}{l}\text { Pericarditis } \\
\text { Pneumonia/ARDS }\end{array}$ & $\begin{array}{l}1 \\
2\end{array}$ \\
\hline $\begin{array}{l}\text { Sepsis } \\
\quad \text { Puerpal streptococcal A sepsis }\end{array}$ & 1 & & \\
\hline $\begin{array}{l}\text { Other indirect causes } \\
\text { Sickle cell anaemia } \\
\text { Systemic lupus erythematodes }\end{array}$ & 6 & $\begin{array}{l}\text { Massive haemolysis } \\
\text { Multiple organ } \\
\text { failure following DIC }\end{array}$ & $\begin{array}{l}1 \\
1\end{array}$ \\
\hline $\begin{array}{l}\text { Breast cancer (metastatic) } \\
\text { Crohn's disease }\end{array}$ & & $\begin{array}{l}- \\
\text { Septic shock }\end{array}$ & $\begin{array}{l}1 \\
1\end{array}$ \\
\hline- & & $\begin{array}{l}\text { Subarachnoid } \\
\text { haemorrhage }\end{array}$ & 1 \\
\hline- & & Pneumococcal sepsis & 1 \\
\hline $\begin{array}{l}\text { Coincidental causes } \\
\text { Car accident }\end{array}$ & $\begin{array}{l}2 \\
2\end{array}$ & Polytrauma & 2 \\
\hline
\end{tabular}

${ }^{a}$ Deaths from cerebrovascular disorders during pregnancy or within 42 days of pregnancy are classified as direct obstetric deaths under ICD-9, but as indirect obstetric deaths under ICD-10.

nities), 11 cases were considered to be indirect maternal deaths (1.7 deaths per 100,000 maternities) and two casualties were classified as coincidental maternal deaths $(n=2)$. Leading causes of maternal deaths were thromboembolism (mean age $=33.9$, range $24.2 .0-41.2$ ), intrapartal and postpartum haemorrhage (mean age $=37.3$, range $33.0-40.5$ ), hypertensive disorders of pregnancy (mean age $=31.2$, range $24.0-39.4$ ), and cardiac disease (mean age $=31.8$, range $24.5-43.7$ ). Thromboembolic complications during pregnancy, labour and puerperium together with intrapartal and postpartum haemorrhage alone, accounted for about half of all maternal deaths (19/37) and were also the strongest determinants of the age-related obstetric risk as measured by the cause-specific maternal death rate.

Fifteen women were nulliparous, and 22 multiparous (median parity $=3$, range $2-10$ ), six of them with a history 
Table 2

Maternal deaths per age category

\begin{tabular}{lcccc}
\hline $\begin{array}{l}\text { Maternal } \\
\text { age }\end{array}$ & $\begin{array}{l}\text { Number of } \\
\text { maternal deaths }\end{array}$ & MMR & RR & $\begin{array}{l}\text { 95\% confidence } \\
\text { interval }\end{array}$ \\
\hline$<20$ & 0 & 0.0 & 0.00 & $0.00-13.12$ \\
$20-29$ & 12 & 2.9 & 1.00 & - \\
$30-34$ & 9 & 5.1 & 1.63 & $0.69-3.86$ \\
$35-39$ & 10 & 22.1 & 7.00 & $3.02-16.20$ \\
$\geq 40$ & 6 & 95.4 & 30.24 & $11.35-80.56$ \\
\hline
\end{tabular}

The $\chi^{2}$-test for trends is highly significant with a $P$-value of $<0.0001$.

of at least one previous caesarean section. Half of the maternal deaths occurred following caesarean delivery (19/37), 13 out of these 19 caesarean sections being elective. To the extent the available data allowed us to, no other obstetric characteristics showed any significant relationship with the risk for pregnancy-associated death in these series. Except for ethnicity, neither did any of the socio-demographic characteristics obtained in the enquiry, such as socio-economic status measured by maternal educational level and occupation allow for risk stratification.

To assess the overall association between maternal age and pregnancy-associated death, five age groups were defined as shown in Table $2(<20 ; 20-29,30-34,35-39$, $\geq 40$ years old). Maternal mortality was strongly related to maternal age, with a relative risk of 7.0 (95\% CI: $3.0-16.2)$ from the age of 35 on, and of 30.0 (95\% CI: 11.4-80.6) in women aged 40 years or beyond (Table 2).

\section{Discussion}

Pregnancy-related deaths in Flanders, Belgium from 1991 to 2000 were identified through linkage of official death certificates and medical birth certificates abstracted from the Birth Registry of the Study Centre for Perinatal Epidemiology. We found a maternal mortality ratio of 5.8/100,000, approximating reported maternal mortality ratio's in most Scandinavian countries [10], though somewhat beneath those recently cited from surrounding countries with rigorous maternal death registration such as The Netherlands [11] and the UK [12]. As part of a confidential enquiry, a standardized questionnaire was administered to the certifying obstetricians and additional information on these maternal deaths was obtained for 34 out of the 37 maternal casualties.

Over the past decade a defined tendency towards delaying maternity is observed and at present nearly half of all births occur to women beyond the age of 30. Consequently, our data show a dramatic increase in both the most prevalent cause-specific obstetric death rates as well as in the overall maternal mortality rate with increasing maternal age. E.g. women aged 35-39 years incur a sevenfold increased risk for pregnancy-associated death when compared to women giving birth in their 20s.

It has been recognized that even in developed countries maternal deaths are generally underreported and therefore underreporting may at least in part explain considerable variation in officially reported maternal death statistics [13]. Maternal deaths during early pregnancy such as those related to interruption, miscarriage and ectopic pregnancy are especially prone to underreporting bias. The latter has been documented in Finland where death certificates of fertileaged women who died were linked to birth, abortion, and hospital discharge registers [14].

Maternal deaths remote from the time of birth are also likely not to be registered as such. Consequently, there has been a plea for adding a specific question on pregnancy to the death certificate. At this time, in most Western European and Nordic countries, including Belgium, Scotland, the Irish Republic, the UK, Germany, France, Denmark, and Norway the death certificate is provided with this so-called 'pregnancy box' $[13,15]$. Similarly, it has been reiterated $[14,15]$ that linkage of death certificates and birth registers may further limit underreporting of pregnancy-associated or late maternal deaths, though at the time of a European comparative study this practice was only adopted by a few countries including Flanders, Belgium and most Scandinavian countries [15].

We therefore suspect that in the present study the actual maternal mortality rate may have been underestimated mainly by not accounting for early pregnancy-related deaths, while late maternal deaths are less likely to be missed by these means of data-collection, as has been documented before for pregnancy-associated deaths in Flanders, Belgium in the MOMS study [15].

Furthermore, though the reported maternal mortality ratio for Flanders, 1991-2000 (MMR = 5.8) is considerably lower than those recently cited for e.g. the The Netherlands, 1996-1998 $(\mathrm{MMR}=14.1)$ [11] and the UK, 1997-1999 [12] $(\mathrm{MMR}=11.4)$ suggesting moderate underreporting, such differences may at least in part be genuine due to differential organisation of obstetric care. For instance, substandard care in both the UK [16] and The Netherlands [17] has largely been attributed to delay referral by either midwife, junior consultant or general practitioner. In Belgium, gynaecologists do most primary maternity care and over $95 \%$ of all deliveries are performed or supervised by a board-certified gynecologist. Therefore, it remains to be established to which extent differences in health services organisation may further contribute to the observed differential maternal mortality rates.

In summary, our results tend to confirm the hypothesis that increasing maternal age is an emerging demographic risk factor for maternal mortality [18], though the latter effect was also partly due to the high proportion of immigrant women with continued childbearing into their later reproductive years. With a growing number of European women postponing maternity for various reasons these data clearly ask for public health scrutiny and in particular for: (1) more research into the underlying causes of the age-related mortality risk in pregnant women and (2) more action and social support so that women can combine career and motherhood. 


\section{References}

[1] Jolly M, Sebire N, Harris J, Robinson S, Regan L. The risks associated with pregnancy in women aged 35 or more. Hum Reprod 2000;15:2433-7.

[2] Ziadeh S, Yahaya A. Pregnancy outcome at age 40 and older. Arch Gynecol Obstet 2001;265:30-3.

[3] Bianco A, Stone J, Lynch L, Lapinski R, Berkowitz G, Berkowitz RL. Pregnancy outcome at age 40 and older. Obstet Gynecol 1996; 87(6):917-22

[4] Gilbert WM, Nesbitt TS, Danielsen B. Childbearing beyond age 40: pregnancy outcome in 24,032 cases. Obstet Gynecol 1999;93:9-14.

[5] Waterstone M, Bewley S, Wolfe C. Incidence and predictors of severe obstetric morbidity: case-control study. BMJ 2001;322(7294):1089-93.

[6] Berg CJ, Chang J, Callaghan WM, Whitehead SJ. Pregnancy-related mortality in the United States, 1991-1997. Obstet Gynecol 2003;101:289-96.

[7] Rutstein DD, Berenberg W, Chalmers TC, Child CG, Fishman AP, Perrin EB. Measuring the quality of medical care - a clinical method. N Engl J Med 1976;294:582-8.

[8] Vleugels A, Bekaert A. The Flemish Centre for the Study of Perinatal Epidemiology and its registry. Qual Assur Health Care 1992;4(2):115-24.

[9] World Health Organization. Manual of the international statistical classification of diseases, injuries and causes of death, 10th revision, vol. 1. Geneva, Switzerland: World Health Organization; 1993.
[10] World Health Organization. Maternal mortality in 1995: Estimates developed by WHO, UNICEF, UNFPA. Geneva, Switzerland: World Health Organization, 2001; report no. WHO/RHR/01.9.

[11] Bennebroek-Gravenhorst J, Van Roosmalen J, Schuitemaker NEW, et al. Toename van de moedersterfte een reden tot ongerustheid? Ned Tijdschr Obstet Gynaecol 2001;114:12-3.

[12] Why Mothers Die 1997-1999. RCOG; 2002.

[13] Schuitemaker NEW. Maternal mortality in Europe present and future. Eur J Obstet Gynecol Reprod Biol 1999;86:129-30.

[14] Gissler M, Kauppila R, Merilainen J, Toukomaa H, Hemminki E. Pregnancy-associated deaths in Finland 1987-1994: benefits of record linkage and definition problems. Acta Obstet Gynecol Scand 1997;76:651-7.

[15] Salavane B, Bouvier-Colle M-H, Varnoux N, Alexander S, Macfarlane Athe MOMS Group. Classification differences and maternal mortality: a European study. Int J Epidemiol 1999;28: 64-9.

[16] de Swiet M. Maternal mortality: confidential enquiries into maternal deaths in the United Kingdom. Am J Obstet Gyneceol 2000;182: 760-6.

[17] Van Roosmalen J, Schuitemaker NWE, Brand R, van Dongen PWJ, Substandard care in immigrant versus indigenous maternal deaths in The Netherlands. Br J Obstet Gynaecol 2002;109:212-3.

[18] Salanave B, Bouvier-Colle MH. The likely increase in maternal mortality rates in the United Kingdom and in France until 2005. Paediatr Perinat Epidemiol 1996;10(4):418-22. 